\title{
Analisis Kegagalan pada Shaft Gearbox Mesin Palletizer di PT Holcim Tbk Tuban
}

\author{
Asia, Lukman Noerochim, dan Rochman Rochiem \\ Departemen Teknik Material dan Metalurgi FTI-ITS, Kampus ITS-Keputih Sukolilo, Surabaya \\ e-mail: lukman@mat-eng.its.ac.id
}

\begin{abstract}
Abstrak-Shaft merupakan bagian yang cukup penting di dalam motor karena shaft berfungsi sebagai penyalur gaya atau tenaga. Shaft bekerja sesuai dengan kerja mesin dan motor. Penelitian ini dilakukan untuk menganalisis penyebab kegagalan yang terjadi pada shaft gearbox mesin palletizer. Beberapa pengujian dilakukan untuk mendukung analisis ini. Dari hasil uji komposisi didapatkan bahwa material shaft tersebut merupakan AISI 1030 dan material shaft tersebut sesuai dengan ASTM A291. Dari pengujian metallography didapatkan hasil struktur mikro yang terdiri dari ferit dan perlit. Pengujian SEM dilakukan pada permukaan patahan dan hasil dari uji SEM menunjukkan adanya retakan dan terdapat garis striasi halus akibat adanya pembebanan berulang dan terus menerus. Uji kekerasan dilakukan pada 2 daerah yaitu daerah dekat patahan dan daerah yang jauh dari patahan. Semakin jauh titik pengujian dari patahan maka hasil kekerasan semakin menurun. Dari hasil analisis rietvield didapatkan nilai regangan dan tegangan sisa pada daerah yang dekat dari patahan lebih besar dari pada daerah yang jauh dari patahan. Pada patahan shaft ini terdapat retakan yang ditandai dengan adanya awal retakan (crack initiation) pada daerah ujung rumah pasak, penjalaran retak (crack propagation) yang ditandai dengan garis pantai dan final fracture dengan permukaan yang kasar.
\end{abstract}

Kata kunci-crack, metallography, palletizer, rietvield, shaft

\section{PENDAHULUAN}

PT HOLCIM Tbk Tuban merupakan perusahaan yang bergerak di bidang industri semen. Produksi semen di Indonesia setiap tahun mengalami kenaikan sehingga perusahaan semen menggunakan beberapa alat atau mesin untuk mendukung produksi semen tersebut. Salah satu mesin yang cukup membantu produksi semen adalah mesin palletizer.

Mesin palletizer berfungsi untuk menyusun atau memindahkan barang produksi ke tempat yg telah disediakan. Mesin palletizer ini dikendalikan secara manual dan semi otomatis. Mesin ini digerakkan oleh sebuah motor. Pada motor tersebut terdapat beberapa komponen penting seperti poros, gear dll. Komponen mesin yang menghubungkan daya dari motor ke mesin yaitu disebut poros atau shaft.

Poros biasanya merupakan material yang terbuat dari baja karbon. Baja karbon yang cocok diaplikasikan untuk poros adalah baja karbon yang cukup kuat yaitu seperti baja karbon menengah. Poros berfungsi untuk meneruskan tenaga baik berupa puntiran, torsi maupun bending dari suatu bagian ke bagian yang lain. Akibat beban tersebut poros mengalami pembebanan yang terus berulang. Akibatnya suatu poros sering mengalami kegagalan dalam operasinya. Kegagalan akibat beban berulang sangat tidak diinginkan karena tanda-tanda akan terjadinya kegagalan tidak dapat diketahui secara langsung. Kegagalan ini dapat berupa crack yang terus berkembang hingga terjadi perambatan crack yang kemudian menjadi patah [1]. Untuk itu perlu dilakukan penelitian untuk mengetahui penyebab-penyebab terjadinya kegagalan pada poros atau shaft.

\section{METODOLOGI PENELITIAN}

Adapun rancangan dan prosedur percobaan akan dijelaskan sebagai berikut:

\section{A. Diagram Alir Penelitian}

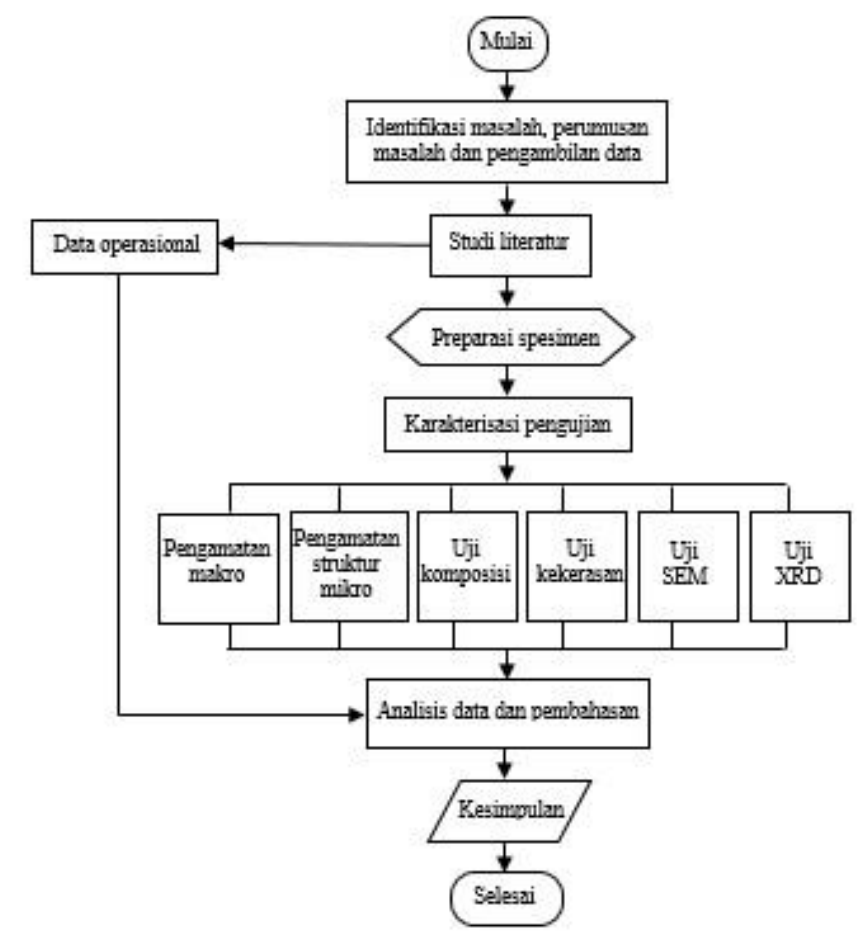

Gambar 1. Diagram Alir Penelitian

B. Peralatan yang digunakan dalampenelitian ini:

1. Penggaris digunakan untuk mengukur spesimen

2. Alat pemotong digunakan untuk memotong spesimen

3. Kamera digunakan untuk melihat kegagalan secara makro

4. Mesin uji kekerasan digunkan untuk mengetahui nilai kekerasan dari spesimen 
5. Peralatan untuk pengujian metalografi seperti amplas grade 80 sampai 2000, mesin polish, dan larutan etsa

6. Mikroskop optik digunakan untuk mengetahui struktur mikro dari shaft

7. Optical Emission Spectrometer digunakan untuk mengetahui komposisi kimia unsur dari shaft

8. SEM digunakan untuk mengetahui karakterisasi pada permukaan patahan

9. XRD digunakan untuk mengetahui fasa dan tegangan sis a material shaft

\section{HASIL DAN PEMBAHASAN}

\section{A. Pengujian komposisi}

Material yang digunakan untuk oenelitian mempunyai komposisi kimia sebagai berikut:

Tabel 1.

Komposisi Kimia Material Shaft yang Dibandingkan dengan ASTM

\begin{tabular}{cccc}
\hline \hline Unsur & Kadar $(\%)$ & $1030($ ASTM A29) & ASTM A291 \\
\hline $\mathrm{C}$ & 0,315 & $0,28-0,34$ & $0,55 \mathrm{max}$ \\
$\mathrm{Si}$ & 0,151 & - & $0,35 \mathrm{max}$ \\
$\mathrm{Mn}$ & 0,771 & $0,60-0,90$ & $0,60-0,90$ \\
$\mathrm{P}$ & 0,0133 & $0,040 \mathrm{max}$ & $0,040 \mathrm{max}$ \\
$\mathrm{S}$ & 0,0190 & $0,050 \max$ & $0,040 \mathrm{max}$ \\
$\mathrm{Cr}$ & 0,198 & - & $0,25 \max$ \\
$\mathrm{Mo}$ & 0,0180 & - & $0,10 \mathrm{max}$ \\
$\mathrm{Cu}$ & 0,180 & - & $0,35 \max$ \\
$\mathrm{Ni}$ & 0,115 & - & $0,30 \mathrm{max}$ \\
$\mathrm{Fe}$ & 98,2197 & - & - \\
\hline \hline
\end{tabular}

Tabel 1 merupakan komposisi kimia material shaft. Jika dilihat dari komposisinya material tersebut termasuk baja karbon menengah yaitu AISI 1030 (ASTM A29). Material tersebut juga sesuai dengan ASTM A291 yang menjelaskan tentang komposisi yang cocok untuk digunakan sebagai shaft.

\section{B. Pengamatan Makro}

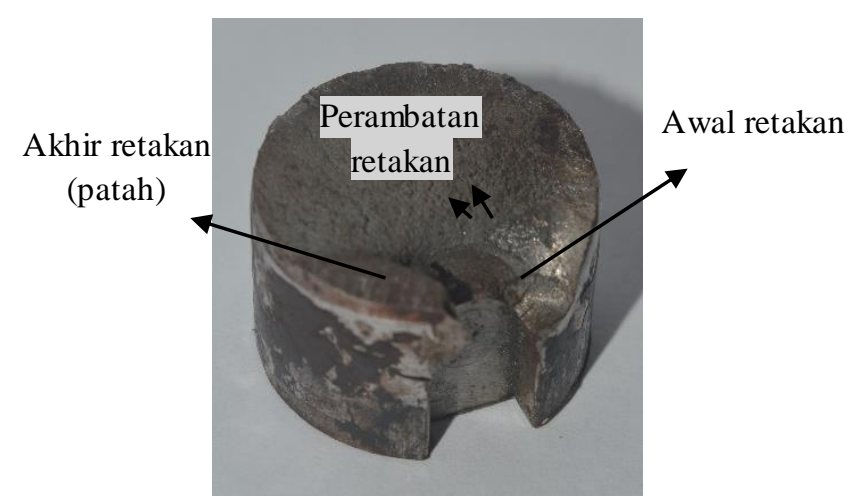

Gambar 2. Permukaan Patahan Shaft

Pada gambar 2 tersebut terlihat jelas pada permukaan patahan terdapat adanya awal retakan, perambatan retak yang ditandai dengan adanya garis pantai dan akhir retakan dengan permukaan yang kasar.

\section{Pengamatan Struktur Mikro}

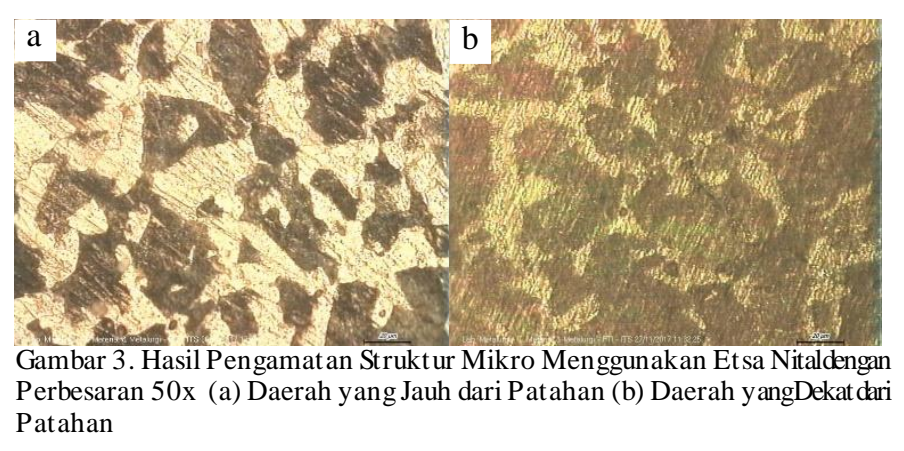

Pada hasil pengamatan struktur mikro terdapat 2 warna yang berbeda yang menandakan pada struktur mikro tersebut terdiri dari 2 fasa yaitu sesuai dengan diagram fasa $\mathrm{Fe}-\mathrm{Fe}_{3} \mathrm{C}$ bahwa dengan kadar karbon 0,3\% maka struktur mikro yang terbentuk adalah ferit (warna terang) dan perlit (warna gelap).

\section{Pengamatan SEM}

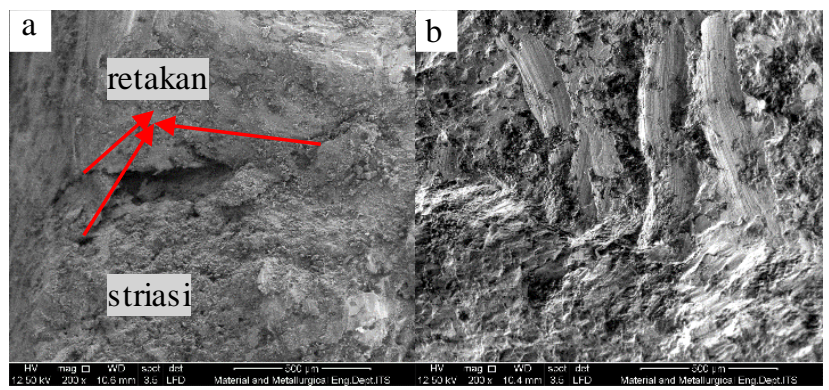

Gambar 4. Hasil Pengamat an SEM (a) Fraktografi Bagian Tepi Permukaan Patahan shaft (b) Fraktografi Akhir Retakan yang Ditandai denganPermukaan Kasar dan Lebih Gelap

\section{E. Pengujian Kekerasan}

Pengujian kekerasan dilakukan pada 2 daerah yaitu daerah yang jauh dari patahan dan daerah yang dekat dengan patahan.

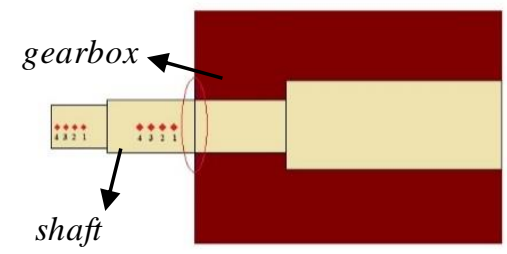

Gambar 5. Titik-titik Pengujian Kekerasan

Hasil yang didapatkan dari pengujian kekerasan yaitu:

Tabel 2.

Kekersan Shaft pada Daerah yang Jauh dari Patahan

\begin{tabular}{ccccc}
\hline \hline Titik & D1 & D2 & HV & BHN \\
\hline 1 & 0,928 & 0,962 & 208 & 198 \\
2 & 0,978 & 0,972 & 195 & 185,5 \\
3 & 0,984 & 0,988 & 191 & 181,9 \\
4 & 1,006 & 1,008 & 183 & 174 \\
& Rata-rata & & 194,25 & 184,85 \\
\hline \hline
\end{tabular}




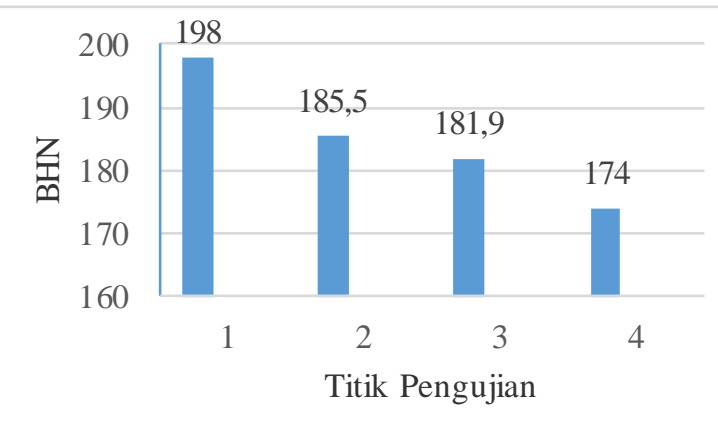

Gambar 6. Distribusi Kekerasan Shaft Daerah yang Jauh dari Patahan

Tabel 3.

Kekerasan Shaft pada Daerah yang Dekat Patahan

\begin{tabular}{ccccc}
\hline \hline Titik & D1 & D2 & HV & BHN \\
\hline 1 & 0,792 & 0,892 & 260 & 247 \\
2 & 0,884 & 0,942 & 222 & 211 \\
3 & 0,878 & 0,964 & 219 & 208,1 \\
4 & 0,932 & 0,954 & 208 & 198 \\
\hline \multicolumn{7}{l}{ Rata-rata } & & 227,25 & 216,025 \\
\hline \hline
\end{tabular}

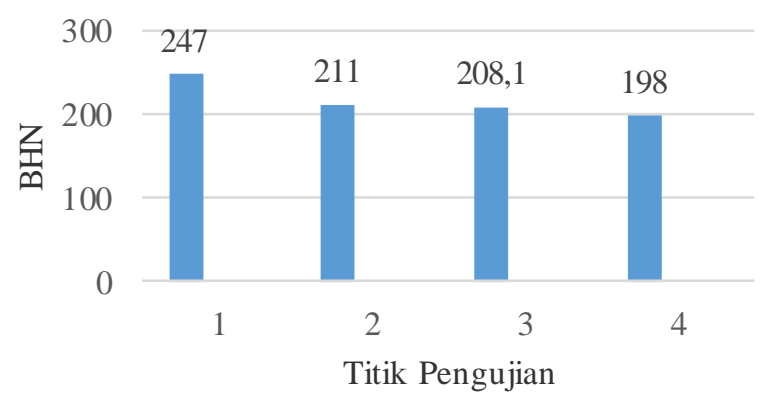

Gambar 7. Distribusi Kekerasan Shaft Daerah yang Dekat dari Patahan

\section{F. Analisis Rietvield}

Analisis rietvield juga dilakukan pada 2 daerah yaitu daerah yang jauh dan dekat dari patahan. Analisis ini bertujuan untuk menganalisis regangan dan tegangan sisa yang terjadi pada material shaft tersebut. Analisis ini menggunakan program rietica dan MAUD berdasarkan data dari pengujian XRD.

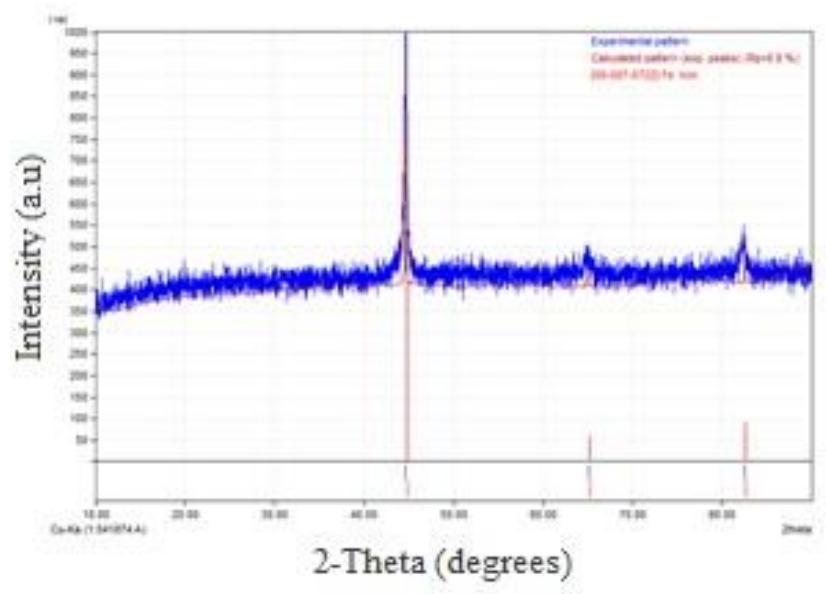

Gambar 8. Hasil Uji XRD pada Daerah yang Jauh dari Patahan

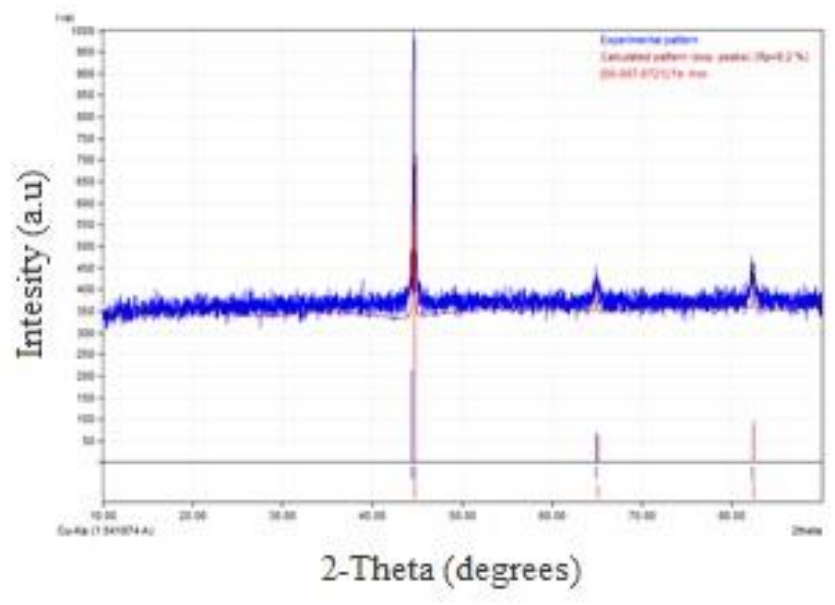

Gambar 9. Hasil Uji XRD pada Daerah yang Dekat dari Patahan

Hasil dari analisis ini dapat dilihat pada table dibawah ini: Tabel 4.

Hasil Output Program Rietica

\begin{tabular}{cccc}
\hline \hline Bagian & Rp & Rwp & $x^{2}$ \\
\hline Jauh dari patahan & 3,93 & 6,13 & 2,93 \\
Dekat dari patahan & 3,67 & 5,94 & 3,23 \\
\hline \hline
\end{tabular}

Tabel 5.

Hasil Perhitungan Regangan dan Tegangan Sisa

\begin{tabular}{ccc}
\hline \hline Bagian & Regangan & Tegangan (MPa) \\
\hline Jauh dari patahan & 0,000157437 & 31,4874 \\
Dekat dari patahan & 0,000551367 & 110,2734 \\
\hline \hline
\end{tabular}

\section{G. Pembahasan}

Berdasarkan hasil uji komposisi unsur kimia menggunakan OES, komposisi kimia dari shaft gearbox tersebut sesuai dengan komposisi kimia material AISI 1030. Shaft ini termasuk baja karbon sedang atau medium. Baja karbon sedang dalam dunia teknik biasanya digunakan sebagai alat-alat perkakas, poros, engkol, roda gigi, ragum, pegas, dan lain-lain. Material yang digunakan sebagai shaft gearbox ini sesuai dengan ASTM A291 tentang penggunaan komposisi kimia material yang cocok digunakan sebagai shaft. Kegagalan yang terjadi pada shaft ini bukan dikarenakan kesalahan pemilihan material. Kegagalan yang terjadi bisa saja disebabkan karena kondisi operasi yang berlebihan, cacat produksi, dan pemeriksaan yang kurang baik [2].

Shaft tersebut menerima pembebanan secara terus menerus baik dari motor maupun mesin. Pada gearbox juga terdapat gear yang memberikan beban torsi kepada shaft. Pembebanan yang didapat shaft dari motor yaitu sebesar 4,99 N.m dan pembebanan yang didapat dari mesin untuk mengangkut 5 kantong semen yaitu sebesar $350 \mathrm{~kg}$. Momen bending dari shaft tersebut yaitu sebesar $342 \mathrm{Mpa}$. Kegagalan shaft juga bisa dikarenakan pembebanan yang berlebihan atau overload. Selain pembebanan yang berlebihan, kegagalan juga bisa disebabkan karena perawatan komponen atau maintenance yang tidak benar sehingga kegagalan tidak bisa dihindari.

Dari pengujian struktur mikro pada gambar 3 didapatkan struktur mikro ferit dan perlit yang mendukung karakterisasi material ini sebagai carbon steel dan juga sesuai dengan diagram fasa $\mathrm{Fe}_{-} \mathrm{Fe}_{3} \mathrm{C}$ bahwa struktur mikro dengan kadar 
karbon $0,3 \% \mathrm{C}$ adalah ferit dan perlit [3]. Pada gambar 3 (a) menunjukkan hasil pengujian struktur mikro material shaft di daerah yang jauh dari patahan. Terlihat hasil dari struktur mikro tersebut terdapat 2 fasa yang berbeda yaitu fasa ferit dan perlit. Fasa ferit terlihat lebih dominan dibandingkan dengan perlit. Hal ini disebabkan karena sifat dari baja dengan kadar karbon $0,3 \% \mathrm{C}$ sedikit ulet sehingga perlit lebih sedikit dari pada ferit. Apabila dilihat dari diagram fasa $\mathrm{Fe}_{-} \mathrm{Fe}_{3} \mathrm{C}$ didapatkan perhitungan perbandingan fasa pada $0,3 \% \mathrm{C}$ yaitu sebagai berikut:

$\boldsymbol{\alpha}=\frac{0,8-0,3}{0,8-0,008} \times 100 \%=63,13 \%$

$\mathbf{p}=\frac{0,3-0,008}{0,8-0,008} \times 100 \%=36,87 \%$

Dari hasil perhitungan terlihat banyaknya fas a ferit dan perlit. Berdasarkan perhitungan dari lever rule diagram fasa $\mathrm{Fe}-\mathrm{Fe}_{3} \mathrm{C}$ yaitu banyaknya perlit hampir setengah dari ferit sehingga sifat dari baja ini tidak terlalu keras

Pada gambar 3 (b) menunjukkan hasil pengujian struktur mikro material shaft di daerah yang dekat dari patahan. Sekilas terlihat tidak ada yang berubah karena struktur yang terbentuk tetap yaitu ferit dan perlit. Akan tetapi, struktur mikro di daerah yang dekat patahan terlihat strukturnya memanjang (terjadi elongation). Terjadinya pertambahan panjang dari struktur mikro material tersebut disebabkan karena terjadi strain hardening pada material sebelum mengalami patah. Strain hardening sendiri yaitu pengerasan regangan yang disebabkan karena pergeseran dislokasi. Dislokasi pada logam semakin rapat dan meningkat serta terjadi pembentukan dislokasi baru. Dengan adanya pembentukan dislokasi baru membuat dislokasi lama terdesak. Pada saat material akan mengalami patah terjadi peregangan sehingga struktur mikro dari material tersebut mengalami penarikan dan membuat struktur mikronya terlihat memanjang.

Material yang mengalami pembebanan pada umumnya akan mengalami peningkatan tegangan dalam yang dikenal dengan strain hardening. Terjadinya strain hardening juga sangat dipengaruhi oleh seberapa besar beban luar yang dikenakan pada material tersebut. Beban yang dikenakan pada material akan menyebabkan material mengalami reaksi terhadap beban tersebut dengan mengalami deformasi yaitu mengalami regangan atau strain. Selama regangan masih dalam batas kemampuan material untuk menahan, maka energi dari luar tersebut yang berupa beban akan digunakan oleh material untuk mengalami peregangan. Akibatnya energi dalam material akan meningkat. Atau hal ini dikenal dengan terjadinya internal stress atau tegangan dalam. Semakin besar tegangan dalam yang terjadi dapat menyebabkan kerusakan atau perpatahan pada material, jika tegangan tersebut melebihi kemampuan kekuatan dari material tersebut [4].

Dari hasil pengamatan makroskopik terlihat jelas dari permukaan patahan terdapat adanya initial crack atau awal retakan yang terdapat di pinggir cekungan. Awal retakan terjadi pada daerah tersebut karena pada daerah tersebut merupakan pusat tegangan sehingga lebih sering terjadi retakan pada daerah tersebut. Retak mulai menjalar dan akhirnya menyebabkan patah yang berujung di daerah seberang terjadinya awal retakan. Pada daerah tengah permukaan patahan material shaft tersebut terlihat adanya garis striasiyang halus. Penjalaran retak disepanjang permukaan patahan ditandai dengan adanya garis pantai. Sedangkan pada akhir patahan terlihat dengan jelas permukaannya lebih kasar.

Hasil uji SEM terlihat pada permukaan patahan terdapat garis striasi halus. Garis striasi yang timbul disebabkan karena adanya pembebanan berulang yang dialami oleh komponen sebelum patah.

Pada gambar 4 merupakan hasil dari uji SEM pada permukaan patahan shaft. Pada gambar 4 (a) menunjukkan hasil fraktografi pada permukaan patahan shaft di bagian tepi. Pada gambar tersebut menunjukkan adanya retakan. Di daerah tersebut juga terlihat adanya garis striasihalus. Adanya retakan menandakan awal terjadinya kegagalan pada material shaft. Pembebanan berulang dan terus menerus yang dialami oleh komponen akan menyebabkan retak yang terbentuk akan mudah menjalar hingga akhirnya mencapai dimensi y ang cukup signifikan untuk menyebabkan komponen patah [5]. Pada gambar 4 (b) merupakan hasil uji SEM pada daerah akhir patahan. Dari hasil SEM tersebut terlihat patahan lebih kasar dan lebih gelap.

Pengujian kekerasan dilakukan pada 2 daerah yaitu daerah yang jauh dari patahan dan daerah yang dekat dengan patahan. Daerah yang jauh dari patahan diambil di ujung material shaft dengan 4 titik pengujian. Titik 1 didapatkan nilai kekerasan 208 HV. Titik 2 didapatkan nilai kekerasan 195 HV. Titik 3 didapatkan nilai kekerasan $191 \mathrm{HV}$ dan titik 4 di ujung shaft didapatkan nilai kekerasan 183 HV. Semakin jauh titik pengujian dari daerah patahan maka kekerasan semakin menurun.

Pengujian kekerasan yang kedua dilakuan pada daerah yang dekat dari patahan. Titik 1 didaerah ujung patahan didapatkan nilai kekerasan 260 HV. Titik 2 didapatkan nilai kekerasan 222 HV. Titik 3 didapatkan nilai kekerasan 219 HV dan titik 4 didapatkan nilai kekerasan 208 HV. Sama halnya pada daerah yang jauh dari daerah patahan, nilai kekerasan akan semakin turun seiring jauhnya titik pengujian dengan patahan.

Dari data hasil pengujian didapatkan nilai kekerasan yang sesuai dengan standar pada ASTM A291. Akan tetapi, pada daerah yang dekat daripatahan didapatkan nilai kekeras an yang lebih tinggi dari nilai kekerasan daerah yang jauh dari patahan. Hal ini disebabkan karena pada daerah yang dekat dari patahan mengalami strain hardening sehingga menyebabkan kekerasan di daerah yang dekat dengan patahan meningkat.

Bila dilihat dari hasil analisis rietvield yang digunakan untuk menghitung analisis regangan dan tegangan sisa dapat dilihat pada tabel 5 bahwa daerah yang dekat dari patahan memiliki nilai regangan dan tegangan sisa yang lebih besardibandingkan dengan daerah yang jauh dari dari patahan. Semakin besar tegangan dalam atau tegangan sisa yang terbentuk dapat menyebabkan kerusakan atau perpatahan pada material jika tegangan tersebut melebihi kemampuan kekuatan dari material tersebut [4].

\section{KESIMPULAN}

Kesimpulan yang dapat diambil dari penelitian ini yaitu :

1. Berdasarkan hasil penelitian didapatkan faktor-faktor penyebab terjadinya kegagalan: 
a. Terjadi strain hardening pada material shaft sebelum patah yang menyebabkan kekerasan material di dekat daerah patahan meningkat dan strain hardening menyebabkan adanya tegangan sisa sehingga menyebabkan komponen patah atau mengalami kegagalan pada material jika tegangan tersebut melebihi kemampuan kekuatan dari material tersebut

b. Terdapat retakan sebelum material patah yang ditandai dengan adanya awal retakan (crack initiation) yang terjadi pada ujung rumah pasak, penjalaran retak (crack propagation) yang ditandai dengan adanya garis pantai dan final fracture dengan permukaan yang kasar. Pada daerah tengah permukaan patahan terdapat garis garis striasi halus yang menandakan adanya pembebanan berulang

c. Kegagalan yang terjadi pada shaft ini bukan dikarenakan kesalahan pemilihan material. Kegagalan yang terjadi bisa saja disebabkan karena kondisi operasi yang berlebihan, cacat produksi, dan pemeriksaan yang kurang baik.

2. Mekanisme terjadinya kegagalan pada kasus ini disebabkan karena ada beban berulang dan terus menerus sehingga pada saat mencapai titik maksimum komponen menerima beban akan menyebabkan komponen patah. Terdapat retakan pada daerah rumah pasak dimana daerah tersebut merupakan daerah terjadinya gesekan antara shaft dengan komponen motor yang lain seperti gear dan daerah tersebut juga merupakan daerah pemusatan tegangan

3. Hal-hal yang perlu dilakukan agar kegagalan shaft tidak terjadi lagi yaitu perlu dilakukan pengecekan secara berkala sehingga bisa langsung ditangani sebelum akhirnya terjadi kegagalan. Hal lain yang perlu diperhatikan yaitu masalah maintenance atau perawatan komponen mesin sehingga bisa meminimalisir terjadinya kegagalan pada shaft maupun komponen motor ataupun mesin yang lainnya.

\section{DAFTAR PUSTAKA}

[1] T. dkk Sugiarto, "Analisis Uji Ketahanan Lelah Baja KarbonSedang AISI 1045 dengan Heat Treatment (Quenching) dengan Menggunakan Alat Rotary Bending," Universitas Lampung, 2013.

[2] A. Brooks, Charlie and Choudhury, Failure Analysis of Engineening Materials. New York: McGraw-Hill, 2002.

[3] W. D. Callister Jr, Materials Science and Engineering an Introduction, 9th Edition. New Jersey: John Wiley \& Sons,Inc,2014.

[4] T. Rusianto, "Pengaruh Tegangan Dalam (Internal Stress)terhadap Laju Korosi pada Baut,” AKPRIND, 2008.

[5] C. dkk Sut owo, "Analisa Kegagalan pada Poros Baja Karbon S45C Aplikasi Komponen As Sink Roll,” Tangerang, 2014. 